\begin{tabular}{|l|l|l||}
\hline \multicolumn{2}{|c|}{ PublisherInfo } \\
\hline \hline PublisherName & $:$ & BioMed Central \\
\hline \hline PublisherLocation & $:$ & London \\
\hline \hline PublisherImprintName & $:$ & BioMed Central \\
\hline \hline
\end{tabular}

\title{
T-cell switch
}

\begin{tabular}{|l|l|l||}
\hline \multicolumn{2}{|c|}{ ArticleInfo } \\
\hline \hline ArticleID & $:$ & 4526 \\
\hline \hline ArticleDOI & $:$ & $10.1186 /$ gb-spotlight-20020711-01 \\
\hline \hline ArticleCitationID & $:$ & spotlight-20020711-01 \\
\hline \hline ArticleSequenceNumber & $:$ & 192 \\
\hline \hline ArticleCategory & $:$ & Research news \\
\hline ArticleFirstPage & $:$ & 1 \\
\hline \hline ArticleLastPage & $:$ & 2 \\
\hline \hline & & RegistrationDate : 2002-7-11 \\
\hline ArticleHistory & $:$ & OnlineDate \\
\hline \hline ArticleCopyright & $:$ & BioMed Central Ltd2002-7-11 \\
\hline \hline ArticleGrants & $:$ & \\
\hline \hline ArticleContext & $:$ & 130593311 \\
\hline \hline
\end{tabular}




\section{Jonathan B Weitzman}

Email: jonathanweitzman@hotmail.com

The reciprocal expression of the two co-receptors CD4 and CD8 define two major subsets of T lymphocytes in the peripheral immune system, namely helper and cytotoxic T cells. In the July 11 Nature, Chi et al. define a role for the SWI/SNF-like BAF chromatin-remodelling complexes in regulating the expression of the $C D 4$ and $C D 8$ genes (Nature 2002, 418:195-199). Chi et al. created transgenic mice expressing mutant forms of the HMG protein BAF57 that disrupt the function of the BAF complex; they found that disruption of BAF function impaired both $C D 4$ silencing and $C D 8$ activation in the thymus. Crossing the BAF mutant mice with mice lacking the $\mathrm{Brg}$ gene, encoding a catalytic subunit of the BAF complex, enhanced the $C D 8$ expression defects without affecting $C D 4$ silencing. Chi et al. go on to show that the BAF complex binds to the characterized CD4 silencer element. Thus, mammalian SWI/SNF complexes appear to be functionally linked to lineage differentiation and T-cell development.

\section{References}

1. The regulation of CD4 and CD8 coreceptor gene expression during T cell development.

2. Nature, [http://www.nature.com]

3. When the SWI/SNF complex remodels...the cell cycle. 